\title{
BIMBINGAN KELOMPOK DENGAN TEKNIK SOSIODRAMA MENINGKATKAN REGULASI EMOSI PADA SISWA SMA DI KOTA BENGKULU
}

\author{
Aisyah Lubis, Yessy Elita, Vira Afriyati \\ Prodi Bimbingan dan Konseling Fakultas Keguruan dan Ilmu Pendidikan \\ Universitas Bengkulu \\ aisyahlubis16@gmail.com,yessyelita@unib.ac.id,vira_afriyati@unib.ac.id
}

\begin{abstract}
ABSTRAK
Tujuan penelitian ini adalah untuk mendeskripsikan pengaruh layanan bimbingan kelompok dengan teknik sosiodrama terhadap regulasi emosi dalam interaksi siswa dengan teman sebaya. Metode dalam penelitian ini adalah metode eksperimen dengan pendekatan Pre Experimental Design. Alternatif pendekatan yang digunakan adalah the one group pretestposttest design. Populasi dalam penelitian ini adalah siswa kelas X IIS 5 SMA Negeri 3 Kota Bengkulu yang berjumlah 34 siswa. Sampel menggunakan teknik purposive sampling. Jumlah sampel adalah 10 siswa. Data hasil penelitian ini dianalisis menggunakan uji z. Hasil penelitian menunjukkan bahwa regulasi emosi meningkat setelah diberikan layanan bimbingan kelompok dengan teknik sosiodrama, hal ini ditunjukkan dengan nilai $\mathrm{z}=-2.803^{\mathrm{a}}$ dengan taraf signifikansi (2-tailed) sebesar 0.005 yang berarti $0.005<0.05$. Temuan ini menunjukkan bahwa ada pengaruh layanan bimbingan kelompok teknik sosiodrama untuk meningkatkan regulasi emosi dalam interaksi dengan teman sebaya siswa kelas X IIS 5 SMA Negeri 3 Kota Bengkulu.
\end{abstract}

Kata kunci: layanan bimbingan kelompok, teknik sosiodrama, regulasi emosi, interaksi teman sebaya

\section{THE INFLUENCE OF THE TUTORING SERVICE GROUP BY USING SOCIODRAMA TECHNIQUE TOWARDS THE REGULATION OF EMOTION IN STUDENT INTERACTIONS WITH PEERS AT SMA 3 KOTA BENGKULU}

\begin{abstract}
The purpose of this study was to describe the influence of the tutoring services group with the techniques of sociodrama towards the regulation of emotional in student interaction with peers. The method in this research is a method of experimentation with approaches Pre Experimental Design. An alternative approach used was the one group pretest-posttest design. The population in this research is the grad X IIS 5 SMA Negeri 3 Kota Bengkulu that add up to 34 students. Sampling used a purposive sampling technique. The number of samples is 10 students. This research data is analyzed using z-test. The results showed that the regulation of emotional escalated after given tutoring service group with sociodrama technique, this is indicated by the value of $\mathrm{z}=-2.803 \mathrm{a}$ a significance level (2-tailed) of 0.005 meaning $0.005<0.05$. This findings that there is an influence of sociodrama technique group tutoring service to improve the regulation of emotion in interaction with peers grade $\mathrm{X}$ student of IIS 5 SMA Negeri 3 Kota Bengkulu.
\end{abstract}

Keywords: group tutoring service group, sociodrama technique, regulation of emotional, peer interaction 


\section{Pendahuluan}

Masa remaja merupakan masa peralihan dari anak-anak menuju dewasa dan merupakan salah satu tahap perkembangan dalam rentang kehidupan manusia. Perubahan banyak terjadi pada individu yang memasuki masa remaja. Perubahan tersebut meliputi semua aspek perkembangan seperti perubahan fisik, emosional, sosial, moral, dan juga kepribadian (Hurlock, 2002: 206). Siswa merupakan remaja yang sedang dalam proses berkembang ke arah kematangan dan salah satunya adalah kematangan emosional. Menurut Sunarto dan Hartono (2013: 26) menyatakan bahwa emosi merupakan gejala perasaan disertai dengan perubahan atau perilaku fisik. Seperti marah yang ditunjukkan dengan teriakan suara keras, atau tingkah laku yang lain. Begitu pula sebaliknya seorang yang gembira akan melonjak-lonjak sambil tertawa lebar, dan sebagainya.

Sementara melihat fenomena yang ada saat ini, remaja sering kali dihadapkan dengan berbagai masalah yang menyangkut aspek emosi. Hal ini terjadi karena ketidakmampuan siswa dalam menjalankan perubahan pada masa remaja. permasalahan tersebut seperti, kasus yang diperoleh melalui media elektronik dan media massa diantaranya yaitu bullying dan aksi berperilaku kasar di media sosial (Liputan 6, Kompas, dan Tempo).

Kasus-kasus di atas merupakan contoh rendahnya kemampuan regulasi emosi pada diri remaja. Menurut Gross (dalam Anggreiny, 2014: 22), bahwa regulasi emosi adalah strategi yang dilakukan secara sadar ataupun tidak sadar untuk mempertahankan, memperkuat atau mengurangi satu atau lebih aspek dari respon emosi yaitu pengalaman emosi dan perilaku. Seseorang yang memiliki regulasi emosi dapat mempertahankan atau meningkatkan emosi yang dirasakan baik positif maupun negatif.

Menurut Sulistyo (2014: 3-4) regulasi emosi adalah kemampuan individu untuk memonitor, mengevaluasi dan memodifikasi emosi yang muncul untuk mencapai tujuan yang meliputi kemampuan mengatur perasaan, reaksi fisiologis, cara berfikir seseorang, dan respon emosi (ekspresi wajah, tingkah laku dan nada suara) sehingga dapat diekspresikan secara tepat dengan lingkungan. Rendahnya kemampuan regulasi emosi pada remaja sering kali menyebabkan remaja cendrung mengalami pertikaian, stres dan bahkan tidak jarang remaja akan mengalami depresi sedangkan remaja yang mampu mengelola 
emosinya akan membantu mereka mengatasi stres dalam kehidupannya dan sebagai bekal awal remaja dalam menghadapi kehidupan mendatang dengan bekal kesehatan mental (Fitriani dan Alsa, 2015: 150).

Berdasarkan hasil observasi yang telah dilakukan peneliti di SMA Negeri 3 Kota Bengkulu, peneliti juga memperoleh beberapa informasi yaitu masih banyak siswa yang belum mampu menjalankan tugas perkembangan sesuai masa remaja seperti hubungan yang terjalin kurang baik antar teman sebaya, melawan guru, kurang sopan, melakukan bullying dengan teman sebaya, dan kurang mampu beradaptasi dengan teman sebayanya. Siswa juga belum mampu memperoleh kematangan yang sesuai dalam dirinya terutama dari aspek emosional dalam berinteraksi dengan teman sebaya.

Menurut Suwatra dan Desia (2013: 152) menyatakan bahwa kelompok teman sebaya merupakan kelompok dari orangorang yang seusia dan memiliki status sama, dengan siapa seseorang umumnya berhubungan atau bergaul. Interaksi seorang siswa dengan teman sebayanya merupakan hal yang sangat penting, karena dari interaksi tersebut siswa mendapat banyak pengetahuan dan pengalaman khususnya dalam bidang sosial dan cara berinteraksi dengan orang lain.

Menurut Krisnamurti (2013: 25-26) bahwa interaksi teman sebaya adalah hubungan timbal balik antara dua individu atau lebih dengan tingkat umur yang berdekatan maupun tingkat kedewasaan yang hampir sama yang saling mempengaruhi, mengubah, dan memperbaiki perilaku atau sebaliknya.

Berdasarkan penjelasan di atas diketahui beberapa masalah diantaranya terdapat siswa di SMA Negeri 3 Kota Bengkulu yang mengalami kemampuan regulasi emosi rendah sehingga terjadi interaksi yang tidak baik antara teman sebaya, bullying, kurang mampu beradaptasi dan bahkan terjadi pertikaian diantara siswa sehingga penulis tertarik melakukan penelitian yang berjudul "Pengaruh Layanan Bimbingan Kelompok Teknik Sosiodrama Terhadap Regulasi Emosi dalam Interaksi dengan Teman Sebaya Siswa SMA Negeri 3 Kota Bengkulu".

Layanan bimbingan konseling adalah pelayanan bantuan untuk peserta didik, baik secara perorangan maupun kelompok, mampu menyelesaikan permasalahan dan mengambil keputusan secara mandiri, berkembang secara optimal dalam bidang 
pengembangan kehidupan pribadi, sosial, belajar, dan karier melalui berbagai jenis layanan dan kegiatan pendukung berdasarkan norma yang berlaku. Salah satu bentuk layanan bimbingan dan konseling sebagai upaya untuk mengatasi kemampuan regulasi emosi dalam interaksi dengan teman sebaya siswa adalah layanan bimbingan kelompok.

Menurut Tohirin (2013: 164) layanan bimbingan kelompok merupakan suatu cara memberikan bantuan (bimbingan) kepada individu (siswa) melalui kegiatan kelompok. Dalam layanan bimbingan kelompok, aktivitas, dan dinamika kelompok harus diwujudkan untuk membahas berbagai hal yang berguna bagi pengembangan atau pemecahan bagi masalah individu (siswa) yang menjadi peserta layanan. Menurut Rusman (2009: 13) bahwa bimbingan kelompok adalah proses pemberian bantuan kepada individu melalui dinamika kelompok dengan berbagi pengalaman dalam upaya pengembangan wawasan, sikap dan/atau keterampilan yang diperlukan dalam upaya mencegah timbulnya masalah atau dalam upaya pengembangan pribadi. Romlah (2001: 13) menyatakan bahwa tujuan bimbingan kelompok yaitu untuk membantu individu menemukan dirinya sendiri, mengarahkan dan dapat menyesuikan diri dengan lingkungannya.

Dalam layanan bimbingan kelompok terdapat beberapa teknik yang dapat digunakan dalam membantu permasalahan yang dialami siswa salah satunya adalah teknik sosiodrama. Teknik sosiodrama merupakan teknik yang tepat digunakan untuk membantu meningkatkan kemampuan regulasi emosi siswa dalam interaksi dengan teman sebaya. Menurut Sanjaya (2012: 160-161) bahwa sosiodrama adalah metode pembelajaran bermain peran untuk memecahkan masalah-masalah yang berkaitan dengan fenomena sosial, permasalahan yang menyangkut hubungan antara manusia seperti masalah kenakalan remaja, narkoba, gambaran keluarga yang otoriter, dan lain sebagainya. Melalui teknik sosiodrama, sebagai strategi pemecahan masalah yang dialami oleh siswa dapat meningkatkan regulasi emosi karena siswa akan diarahkan untuk mengembangkan sikap kritis terhadap tingkah laku atau perbuatan yang harus diambil/ jangan diambil dalam situasi tertentu menyangkut regulasi emosi.

Menurut Winkel (2004: 470) sosiodrama adalah salah satu teknik dalam bimbingan kelompok yaitu teknik bermain peran (role playing) dengan cara 
mendramatisasikan bentuk tingkah laku dalam hubungan sosial. Selain itu siswa juga diarahkan mengembangkan sikap empati dalam dirinya yaitu dimana siswa akan memahami pikiran, perasaan, dan maksud orang lain serta pengertian sosial yakni mengetahui bagaimana dunia sosial bekerja (Goleman dan Daniel, 2007: 114).

\section{Metode Penelitian}

Metode yang digunakan dalam penelitian ini adalah metode eksperimen, dengan pendekatan Pre Exsperimental Design. Pre Expereimental Design, merupakan desain sungguh-sungguh. Masih terdapat variabel luar yang ikut berpengaruh terhadap terbentuknya variabel dependen. Alternatif pendekatan Pre Exsperimental Design yang digunakan dalam penelitian ini adalah the one group pretest-posttest designyaitu terdapat pretest sebelum diberikan perlakuan, hasil perlakuan dapat diketahui dengan lebih akurat, karena dapat membandingkan dengan keadaan sebelum diberikan perlakuan (Sugiyono, 2011: 73).

Penelitian ini dilakukan dengan dua kali pengukuran. Pengukuran pertama dilakukan sebelum teknik sosiodrama. Pengukuran kedua dilakukan setelah teknik sosiodrama dilakukan kepada subjek penelitian. Dantes (2012: 94) juga menyatakan bahwa dalam eksperimen harus terdapat perlakuan (treatment), yaitu sesuatu yang mungkin menjadi penyebab. Sedangkan efek perlakuan itu adalah hasil (outcome).Desain tersebut digambarkan sebagai berikut :

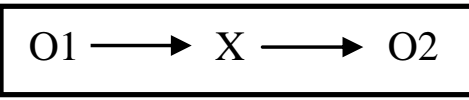

Keterangan :

$$
\begin{aligned}
\mathrm{O} 1= & \text { Pengukuran sebelum teknik } \\
& \text { sosiodrama dilakukan kepada } \\
& \text { subjek. } \\
\mathrm{X}= & \text { Teknik sosiodrama. } \\
\mathrm{O} 2= & \text { Pengukuran sesudah teknik } \\
& \text { sosiodrama kepada subjek. }
\end{aligned}
$$

Sampel yang digunakan dalam penelitian ini berjumlah 10 siswa dengan kriteria memiliki regulasi emosi rendah dalam interaksi dengan teman sebaya. pengambilan sampel menggunakan teknik purposive sampling, yaitu pengambilan sampel sumber data dengan pertimbangan tertentu (Sugiyono, 2013: 218-219).

Teknik pengumpulan data menggunakan angket dengan model skala Likert. Menurut Sugiyono (2011: 93) skala Likert digunakan untuk mengukur sikap, pendapat, dan persepsi seseorang atau sekelompok orang tentang fenomena sosial. Dalam skala Likert, variabel dijadikan sebagai aspek yang akan diukur selanjutnya 
dijabarkan menjadi indikator variabel. Kemudian indikator tersebut dijadikan sebagai titik tolak untuk menyusun aitemaitem instrumen yang dapat berupa pernyataan atau pertanyaan. Jawaban setiap aitem pertanyaan yang menggunakan skala Likert mempunyai gradasi dari sangat positif sampai dengan negatif. Penilaian skala Likert dapat dilihat pada tabel 1, sebagai berikut:

Tabel 1. Skala Likert

\begin{tabular}{cccc}
\hline No & \multicolumn{3}{c}{ Pernyataan } \\
& Pilihan/ & Favorable & Unfavorable \\
\multicolumn{1}{r}{} & Jawaban & $(+)$ & $(-)$ \\
1. & SS & 5 & 1 \\
2. & S & 4 & 2 \\
3. & KS & 3 & 3 \\
4. & TS & 2 & 4 \\
5. & STS & 1 & 5 \\
\hline
\end{tabular}

Keterangan :

SS : Sangat Sesuai

$\mathrm{S} \quad$ : Sesuai

KS : Kurang Sesuai

STS : Sangat Tidak Sesuai

TS : Tidak Sesuai

Teknik analisis data menggunakan uji validitas, reliabilitas, daya beda aitem dan uji hipotesis. Pada pengujian reliabilitas diperoleh Cronbach's Alpha sebesar 0.801.

\section{Hasil dan Pembahasan}

Analisis hasil pre-test dan post-test regulasi emosi siswa kelas X IIS 5 SMA Negeri 3 Kota Bengkulu.

Tabel 2. Penentuan Kategori

\begin{tabular}{cc}
\hline Skor & Kategori \\
\hline$\geq 84$ & Sangat Tinggi \\
$76-83$ & Tinggi \\
$67-75$ & Sedang \\
$51-66$ & Rendah \\
$\leq 50$ & Sangat Rendah \\
\hline
\end{tabular}

Pre-test

Hasil pre-test yang diperoleh siswa adalah sebagai berikut:

Tabel 3. Frekuensi Pre-test

\begin{tabular}{ccc}
\hline \multicolumn{2}{l}{ Interval Frekuensi } & Kategori \\
$\geq 84$ & - & Sangat Tinggi \\
$76-83$ & - & Tinggi \\
$67-75$ & 8 & Sedang \\
$51-66$ & 2 & Rendah \\
$\leq 50$ & - & Sangat Rendah \\
Total & 10 & \\
\hline
\end{tabular}

Berdasarkan hasil pre-test diperoleh kategori yang memiliki regulasi emosi rendah sebanyak 2 orang dengan persentase $20 \%$ dan interval 51-66. Regulasi emosi dengan kategori sedang sebanyak 8 orang 
siswa dengan persentase $80 \%$ dan interval 67-75. Rata-rata (mean)

yang diperoleh sebesar 69,8. Sampel yang temasuk dalam kategori regulasi emosi rendah dan sedang akan diberikan perlakuan (treatment) berupa bimbingan kelompok dengan teknik sosiodrama.

\section{Post-test}

Setelah melakukan post-test dengan memberikan angket kepada sepuluh orang siswa, maka diperoleh hasil sebagai berikut

Tabel 4. Frekuensi Post-test

\begin{tabular}{ccc}
\hline Interval & Frekuensi & Kategori \\
$\geq 84$ & 4 & Sangat Tinggi \\
$76-83$ & 5 & Tinggi \\
$67-75$ & 1 & Sedang \\
$51-66$ & - & Rendah \\
$\leq 50$ & - & Sangat Rendah \\
Total & 10 & \\
\hline
\end{tabular}

Berdasarkan hasil post-test diperoleh hasil peningkatan regulasi emosi siswa yang semula berada dalam kategori rendah dan sedang. Peningkatan yang terjadi yaitu 5 siswa menjadi berada pada kategori tinggi yaitu memperoleh persentase sebesar $50 \%$ dengan interval 76-83 dan 4 siswa pada kategori sangat tinggi yaitu memperoleh persentase sebesar $40 \%$ dengan interval $\geq$ 84 dan 1 siswa pada kategori sedang yaitu mengalami peningkatan skor dengan persentase $10 \%$ dan rata-rata (mean) sebesar 84 .

\section{Uji Hipotesis}

Tabel 5. Hasil Uji Hipotesis

\begin{tabular}{lr}
\hline & Postest - Pretest \\
$\mathrm{Z}$ & $\mathbf{- 2 . 8 0 3 ^ { \mathbf { a } }}$ \\
Asymp. Sig. (2 & $\mathbf{. 0 0 5}$ \\
tailed) & \\
\hline
\end{tabular}

Berdasarkan taraf signifikansi (2tailed) > 0.05 maka Ho diterima. Hasil perhitungan diperoleh nilai signifikan sebesar 0.005 yang berarti $0.005<0.05$ sehingga Ho ditolak, Ha diterima. Oleh karena itu dapat disimpulkan bahwa ada pengaruh layanan bimbingan kelompok teknik sosiodrama untuk meningkatkan regulasi emosi dalam interaksi dengan teman sebaya siswa kelas X IIS 5 SMA Negeri 3 Kota Bengkulu.

\section{Kesimpulan}

Berdasarkan hasil penelitian yang telah dilakukan dapat ditarik kesimpulan sebagai berikut:

1. Kemampuan regulasi emosi dalam interaksi siswa dengan teman sebaya yang dialami sebelum diberikan layanan bimbingan kelompok dengan teknik sosiodrama, ditemukan 2 siswa dalam 
kategori rendah dan 8 siswa dalam kategori sedang dengan rata-rata

(mean) sebesar 69,8. Sehingga kemampuan regulasi emosi siswa dalam interaksi teman sebaya dikatakan berada pada kategori rata-rata rendah.

2. Kemampuan regulasi emosi dalam interaksi siswa dengan teman sebaya setelah diberikan layanan bimbingan kelompok teknik sosiodrama yang pada awalnya berada 2 siswa dikategori rendah meningkat menjadi tinggi dan sangat tinggi dan 8 siswa berada pada kategori sedang meningkat menjadi kategori tinggi, sangat tinggi dan 1 siswa berada pada kategori sedang, tetapi mengalami peningkatan nilai dengan rata-rata (mean) sebesar 84. Sehingga terjadi pengaruh regulasi emosi dalam interaksi siswa dengan teman sebaya berada pada kategori rata-rata tinggi. Peningkatan dari sebelum diberikan layanan dan sesudah layanan diperoleh rata-rata (mean) sebesar 14,2.

3. Ada pengaruh dari perlakuan (treatment) menggunakan layanan bimbingan kelompok dengan menggunakan teknik sosiodrama untuk meningkatkan kemampuan regulasi emosi siswa dalam interaksi siswa dengan teman sebaya. Hal ini dapat dibuktikan dari hasil analisis data yang menyebutkan bahwa Ho ditolak dan Ha diterima yang berarti terdapat peningkatan kemampuan regulasi emosi dalam interaksi siswa dengan teman sebaya setelah diberikan layanan bimbingan kelompok dengan teknik sosiodrama.

\section{Daftar Pustaka}

Anggreiny, Nila. (2014). "Rational Emotive Behaviour Therapy (REBT) untuk Meningkatkan Regulasi Emosi pada Remaja Korban Kekerasan Seksual”. Tesis. Magister Psikologi Profesi Kekhususan Klinis Anak : Universitas Sumatera Utara.

Fitriani, Yulia \& Alsa, Asmadi. (2015). "Relaksasi Autogenik untuk Meningkatkan Regulasi Emosi pada Siswa SMP ISSN : 2407-7801 di UGM", Journal of Psychology, Vol. 1, No. 3 : 149-162.

Goleman \& Daniel. (2007). Social Intelligence: Ilmu Baru tentang Hubungan Antar Manusia. Jakarta : Gramedia Pustaka Utama.

Hurlock, Elizabeth B. (2002). Psikologi Perkembangan edisi ke-5. Jakarta : Erlangga.

Krisnamurti, Ria. (2013). "Pengaruh Pola Asuh Orang Tua dan Interaksi Teman Sebaya Terhadap Kecerdasan Emosi Siswa Kelas VB SD Negeri Pujokusuman 1 Tahun Ajaran 2012/2013". Skripsi. Fakultas Ilmu Pendidikan : Universitas Negeri Yogyakarta. 
Romlah, Tatiek. (2001). Teori dan Praktek Bimbingan Kelompok. Malang : Universitas Negeri Malang.

Rusman. (2009). Manajemen Kurikulum. Jakarta. Raja Grafindo Persada.

Sanjaya, Wina. (2012). Strategi Pembelajaran Berorientasi Standar Proses Pendidikan cetakan ke-2. Jakarta : Kencana Media Group.

Sugiyono. (2011). Metode Penelitian Kuantitatif Kualitatif dan $R \& D$. Bandung : Alfabeta.

Sulistyo, Ery. (2014). "Hubungan Antara Regulasi Emosi dengan Kecemasan Menghadapi Pertandingan”. Skripsi. Fakultas Psikologi : Universitas Muhammadiyah Surakarta.

Sunarto, H \& Hartono, Agung. (2013). Perkembangan Peserta Didik. Jakarta : Rineka Cipta.

Suwatra \& Desia. (2013). Sosiologi Pendidikan. Singaraja : Undiksha.

Tohirin. (2013). Bimbingan dan Konseling di Sekolah dan Madrasah (berbasis integrasi). Jakarta : Grafindo Persada.

Wingkel. (2004). Bimbingan dan Konseling di Institusi Pendidikan. Jakarta : Gramedia. 